\title{
POLSKIE PARTIE SOCJALISTYCZNE WOBEC SWIĄT RELIGIJNYCH NA PRZELOMIE XIX I XX WIEKU
}

W najbardziej okazałych i uroczystych dorocznych świętach katolickich w Polsce uczestniczyła praktycznie cała ludność. Można było nie iść do spowiedzi i komunii wielkanocnej czy na cotygodniowe nabożeństwo, można było zaniedbywać posty i codzienną modlitwę, ale nie wypadało być nieobecnym na pasterce, rezurekcji czy na rozbudowanych i mających bogatą oprawę nabożeństwach świątecznych. Nie godziło się też zapominać o żłobkach i o grobach w kościołach. W większych miastach w czasie Bożego Narodzenia i Wielkanocy widziano całe rodziny pielgrzymujące $\mathrm{z}$ jednego kościoła do drugiego. Wśród nich byli Polacy innych wyznań. Trudno się temu dziwić, gdyż były to zwyczaje i obrzędy religijne silnie wrośnięte w polski krajobraz, stanowiły cząstkę ogólnonarodowej kultury. Tadeusz Boy-Żeleński pisał, iż „groby, nabożeństwa majowe, Boże Ciało, Lajkonik, wianki, pasterka wyznaczały pory życia ówczesnego Krakowa" i - dodajmy - nie tylko Krakowa ${ }^{1}$.

W świętach dorocznych uczestniczyli również indyferentni religijnie, na co dzień dalecy od spraw religii, a nawet wolnomyśliciele ${ }^{2}$. „A jednak u nas ludzie nawet niewierzący i wolnomyśliciele czy nie chcieli, czy to nie mieli odwagi i energii zerwać wszelką łączność — wszelki swój współudział w tych pogań-

\footnotetext{
${ }^{*}$ W przypisach i tekście zastosowano następujące skróty:

CAKC - Centralne Archiwum KC PZPR

KPP - Komunistyczna Partia Polski

PPS - Polska Partia Socjalistyczna

PPSD - Polska Partia Socjaldemokratyczna

PGZŻ - Piotrkowski Generalny Zarząd Żandarmerii

SDKPiL - Socjaldemokracja Królestwa Polskiego i Litwy

SKKr $\quad$ - Sąd Koronny Krakowski

StGrKr - Starostwo Grodzkie Kraków

TGG Kal - Tymczasowy Generał Gubernator Kaliski

WAP - Wojewódzkie Archiwum Państwowe.

zp - zabór pruski

${ }^{1}$ Zob. Historia katolicyzmu spotecznego w Polsce, Warszawa 1981, s. 141. W Europie zachodniej wielu Francuzów, Belgów, Niemców zachowywało - jak to określił G. Clemenceau - „obyczaj kultu", przynajmniej w najbardziej uroczystych chwilach ludzkiej egzystencji.

${ }_{2}$ Bynajmniej nie było to przykładem polskiej specyfiki, skoro również praktykowali niewierzący Francuzi czy Belgowie; por, F. A. Is a m b e r t, La Fin de l'année. Etude sur les fêtes de Noël et du Nouvel An à Paris, Paris 1982 (maszynopis w Bibliotheque de la Sorbonne).
} 
skich, burżuazyjnych uroczystościach"3. Pretensje te kierowane przez polskich anarchistów i radykalne koła wolnomyślicieli do niewierzących — praktykujących nie na wiele się zdały w obliczu siły tradycji i nacisków opinii publicznej.

Wśród tekstów zamieszczonych w drukach partyjnych czy wygłaszanych podczas zebrań kólek robotniczych, trudno by szukać takich, które by w sposób programowy, pełny odzwierciedlały stosunek polskich socjalistów, poszczególnych partii socjalistycznych do świąt chrześcijańskich, teraz jak i w przyszłości, do ich warstwy religijnej, obrzędowej, ludowej. W tej sytuacji jesteśmy skazani na odtwarzanie rzeczywistego stanowiska w oparciu o rozproszone i ułamkowe wypowiedzi i oceny. Najczęściej na ten temat socjaliści polscy pisali i mówili z okazji świąt Bożego Narodzenia i Wielkanocy, mniej z okazji Zielonych Świąt, Wigilii św. Jana i Wszystkich Swiętych. Na inne święta doroczne nie zwracali już uwagi. $Z$ tytułu świąt, a zwłaszcza Bożego Narodzenia i Wielkanocy, w dziennikach partyjnych, często i w tygodnikach oraz w niektórych niesystematycznie wydawanych periodykach, a nawet w pismach poważnych, adresowanych do inteligencji, zamieszczano specjalne materiały świąteczne. Regularnie czyniły to redakcje „Naprzodu”, „Nowego Robotnika”, „Prawa Ludu”, „Metalowca” - wszystkie PPSD, „Gazety Robotniczej” (PPSzp) oraz rzadziej, gdyż nieregularnie się ukazywały — „Robotnika” i „Górnika” (PPS).

W krajach Europy zachodniej, we Francji czy w Belgii trudno szukać gazet socjalistycznych, które by, podobnie jak polskie, regularnie zamieszczały materiały świąteczne. Tamtejsze partie widocznie uznały ten temat za prywatny i mało przydatny dla celów propagandowych, uświadamiających. Poza tym święta katolickie odgrywały tam zasadniczo mniejszą rolę niż w Polsce, gdzie ich wagę podnosił wymiar narodowy, a nie tylko rodzinny i religijny.

W polskiej prasie, najwięcej informacji na temat stanowiska socjalistów wobec świąt dorocznych można spotkać w redakcyjnych artykułach wstępnych oraz w korespondencjach świątecznych. Niemało również w okolicznościowych wierszach, opowiadaniach, nowelach Gustawa Daniłowskiego, Andrzeja Struga, Marii Markowskiej, Emila Haeckera, autorów anonimowych ukrywających swoją tożsamość pod pseudonimami oraz w specjalnie wydawanych świątecznych drukach ulotnych ${ }^{4}$.

We wszystkich tych tekstach uderza podobieństwo oceny klasowej funkcji i roli świąt religijnych. Twierdzi się zatem, iż dobrze one służą, ale tylko posiadaczom i Kościołowi, gdyż „tumanią biednych, zaciemniają obraz nędzy i krzywdy społecznej"5. Stwarzają niebezpieczną iluzję harmonijnej współpracy i braterstwa świata pracy i kapitału, zgodnie bowiem z nauczaniem Kościoła

\footnotetext{
${ }^{3}$ WAP Kraków: SKKr 1211 Pr. 14/7 (s. 10 - 11: przemówienie J. Zielińskiego).

${ }^{4}$ Sporo ciekawych spostrzeżeń możemy spotkać $w$ wydawanych specjalnie do żolnierzy armii rosyjskiej stacjonujących w Królestwie odezwach świątecznych, m. in. „Prazdnik Rażdistwa Chrystowa, Mir na ziemli i człowieciech błagowolenije".

5 ,Metalowiec” 25 XII 1909 nr 52.
} 
mogą być czasem pokoju publicznego i klasowego, pojednania wszystkich wierzących bez różnicy pochodzenia i majątku. W sytuacji, gdy istnieją rażące sprzeczności między fabrykantami i robotnikami, nie możemy się zgodzić powiadali socjaliści — z taką ideą świąt. Lud roboczy — podkreślali — nie ma powodów aby identyfikować się ze świętami posiadaczy, by się weselić i radować. „Wesołe Alleluja nie dla ludu”. „Wesoły nam dzień dziś nastał” Czy lud będzie te słowa wygłaszał i będzie drwił sam z siebie? I czy lud polski bity, poniżany, zmuszany do emigracji... znajduje się w takim nastroju do śpiewu? Czy jest on w stanie unieść duszę do Wesołego Alleluja?6.

Socjaliści stale podkreślali, iż uczestnicząc w świętach chrześcijańskich, robotnicy, chłopi i rzemieślnicy powinni z tego wszystkiego zdawać sobie sprawę, ale „nadejdzie dzień, kiedy i dla nas zabrzmią wesoło pieśni świąteczne”, gdy ulegną zmianie dotychczasowe niesprawiedliwe stosunki społeczne i polityczne. Jak pisała „Gazeta Robotnicza” nasze wesołe święta leżą w tej wielkiej, świetlanej, szczęśliwej przyszłości, która dla ludu polskiego zabłyśnie wtedy, gdy nad ziemią naszą, od jednego jej końca do drugiego powieje czerwony sztandar"7. Socjaliści zapowiadali, że być może nastąpi to już w niedalekiej przyszłości, a wtedy święta chrześcijańskie będą mogły być w jednakowym stopniu dla wszystkich. Staną się prawdziwie ludowymi, robotniczymi świętami. $\mathrm{Ci}$, którzy wierzą będą je obchodzili zgodnie z zasadami ich wiary, „ci zaś, którzy uznali religię za brzemię siebie niepożyteczne, w świętach będą mogli znaleźć tylko chwile wypoczynku i serdecznej pogawędki z przyjacioły"8. Dzisiaj — dodawali - jedynie Zielone Swiątki można uważać za święto ustanowione z myślą o ludziach pracy fizycznej: na cześć ludzi pracy, uczniów Chrystusa, którzy rozbiegli się po świecie tworząc gminy komunistyczne.

Dla socjalistów, zwłaszcza z partii legalnych, PPSD i PPS zaboru pruskiego święta kościelne to również dobre okazje do rozważań na temat różnic socjalnych, albowiem na ich przykładzie wyjątkowo przekonywająco widać to wszystko co dzieli świat pracy i kapitału, bogaczy i biedaków. Socjaliści sięgali nie tylko do obrazów Bożego Narodzenia czy Wielkanocy, lecz także do Wszystkich Świętych. „Idziemy popatrzeć się na groby, te ciche, smutne, nieoświetlone a zobaczymy i te drugie wspaniałe blaskiem lampionów i uderzające zapachem kwiatów, a kontrast ten doda nam sił do walki i zwycięstwa"9.

Kościół i katolicka opinia publiczna, odbierały uwagi socjalistów polskich na temat świąt, jako zapowiedź walki o ograniczenie ich znaczenia, a w przyszłości, w nowym systemie politycznym - nawet likwidacji ${ }^{10}$. „Socjalizm -

6 „Gazeta Robotnicza” 4 IV 1896 nr 4.

7 "Gazeta Robotnicza" 24 XII 1903 nr 102.

8 "Gazeta Robotnicza" 26 XII 1896 nr 52.

9 "Glos" (Lwów) 3 X 1906 nr 42.

10 M. in. „Gwiazdka Cieszyńska”, powolując się na prasę socjalistyczną partii zachodnich, dowodzila, iż socjaliści chcą zniszczyć, znieść święta katolickie $(1893 \mathrm{nr} 118,1894 \mathrm{nr} 70,1896 \mathrm{nr} 8$, $1900 \mathrm{nr} 144)$. 
twierdził ks. Badolski w kościele św. Marcina we Lwowie - chce znieść wszystkie święta kościelne, a ustanowić nowe jakieś swoje"11. Był to jeden z koronnych, często wysuwanych zarzutów pod adresem socjalistów.

$\mathrm{W}$ istocie mimo negatywnej oceny funkcji świąt katolickich, dalecy oni byli od postawienia programowego żądania ich likwidacji nawet w dalszej przyszłości, choć swój głos za zachowaniem świąt oddawali z innych pobudek niż Kościół czy osoby wierzące ${ }^{12}$. Twierdzili, iż w przeciwieństwie do religii święta są silnie i na trwałe osadzone w ludzkim doświadczeniu, są autentycznym wyrazem potrzeb człowieka, który powinien mieć możliwość ich zaspokojenia bez żadnych przeszkód. „My nie myślimy wcale znosić świąt przeznaczonych na wypoczynek. Nie myślimy więc skreślać takich świąt jak np. wigilia”, „nie myślimy zniweczyć dni, w które by ludziska mogli się schodzić na wspólną pogawędkę lub gwoli wesołości"13. Podobnymi refleksjami z czytelnikiem dzielił się J. Marchlewski: „Szczególnie trwałe jest jednak przywiązanie do obrzędowości religijnej, tak silnie zakorzenionej wśród katolików polskich. Tradycji tej nie należy odrzucać ze względu na koloryt obyczajowy będący wyrazem kultury ludowej" 14 .

Dla polskich socjalistów, a przynajmniej dla członków PPS, PPS zaboru pruskiego i PPSD, istotnym walorem świąt katolickich był też ich jednoznacznie narodowy charakter. Dobrym potwierdzeniem tego były przykłady obrony przez PPS w zaborze rosyjskim, prawa robotników do wolnych od pracy świąt kościelnych. Akcjom tym, co jest zrozumiałe socjaliści nadawali niemały rozgłos. Szczególny charakter miał konflikt w Królestwie Polskim między polskimi robotnikami a carską władzą, która próbowała zmusić ich do uczestniczenia w świętach prawosławnych oraz do pracy w niektóre święta katolickie. Praktyki rządu carskiego były jedynym z przykładów akcji mającej na celu narzucanie prawosławia i rusyfikacji. Oba zadania, tj. rusyfikację i szerzenie prawosławia, władze carskie traktowały z równą powagą. W obronie prawa robotników do wolnych od pracy świąt stanąła PPS: „swoich świąt — pisał „Robotnik” nie dajcie sobie wydrzeć, a za narzucone święta prawosławne, władza powinna płacić jak za zwykły dzień roboczy"15. Praca w święta katolickie i brák wynagrodzenia za święta prawosławne oznaczałyby rezygnację z praw, które im się jako „robotnikom polskim i wierzącym katolikom przynależą”. PPS pojmowa-

11 „Robotnik” (Lwów) 9 XII 1892 nr 23.

12 Jednoznacznie od polskich socjalistów różnili się francuscy allemaniści i blankiści, którzy uważali, iż księża za pośrednictwem „pożałowania godnych ceremonii religijnych i świąt” narzucają swoją wolę „naíwnym wierzącym”. Dlatego socjaliści, wolnomyśliciele, anarchiści winni całkowicie ignorować święta chrześcijańskie; zob. „L'Ami de Peuple” 9 I 1876 nr 2; „Le Prolétariat” 28 II $1885 \mathrm{nr} 48$.

13 „Gazeta Robotnicza” 26 XII 1896 nr 52.

14 J. Marchlew ski, Ludzie, czasy, idee, Warszawa 1973, s. 73 - 74.

15 „Robotnik” 26 X 1903 nr 52. 
la obronę świąt jako obronę narodowej godności oraz polskiego stanu posiadania. „Trzeba szanować - pisano — swą godność „narodową”16.

Opowiadając się za zachowaniem świąt, jednocześnie socjaliści oświadczali, iż będą się starali nadawać im inną treść, nowy laicki wymiar. Najwyraźniej mówiła o tym podczas rewolucji 1905/07 SDKPiL. Podkreślała, iż socjaldemokraci w świętach widzą co innego niż ludzie wierzący. „Dla nas, dla bojowników rewolucji - pisal „Czerwony Sztandar” — owe dni „bożego narodzenia” również są symbolem, lecz nie w znaczeniu, które im nadała idea judeochrześcijańska, nie w znaczeniu odkupienia ,win i wybawienia” przez bóstwo i fatum, lecz w znaczeniu innym, wszechludzkim"17.

Socjaliści polscy zmierzając do stopniowej reinterpretacji sensu świąt katolickich, do eliminowania i zawężania treści religijnych nie kwestionowali jednak, nie podawali w wątpliwość potrzeby zachowania świątecznych ceremonii religijnych. Nabożeństwa świąteczne, skupienia modlitewne wiernych, śpiew pieśni religijnych - to wszystko leżało poza ich zainteresowaniami. Uważali bowiem, iż jest to sfera czysto osobista wierzących. Jedynie sporadycznie mogliśmy napotkać uwagi, iż dla socjalistów święta nie są czasem modlitwy. „Dla nas dzień zmarłych jest dniem pamiątki..., nie dniem modłów za pomarłych! Ale jeśli ludzie jeszcze się modlą szczególnie „gorąco w okresie świąt, to jest to coś czasowego, gdyż niedługo z biegiem postępu odpadnie i modlitwa"18.

Należy się zastanowić w jaki sposób partie socjalistyczne zamierzały doprowadzić do stopniowej laicyzacji sensu i znaczenia świąt? Przede wszystkim wystrzegały się kroków, które by w sposób bezpośredni podważały ich religijny charakter. Szukały zatem różnych dróg pośrednich. Jedną z nich było kwestionowanie prawdziwości ewangelicznych opowieści o narodzeniu, śmierci i zmartwychwstaniu Chrystusa. Ze względu na „delikatność kwestii” socjaliści starali się o tym mówić i pisać w sposób możliwie taktowny i delikatny. Swiadczą o tym choćby takie słowa jak: „cudna legenda”, „wspaniała, krzepiąca baśń, legenda o narodzinach Pana Jezusa”, „,baśń o zmartwychwstaniu”, „Legenda prześliczna tworzona chyba przez wielką miłość dla ludu”, „natchnione podanie o zesłaniu Ducha św.”, „cudowna, urodziwa baśń o narodzeniu”, „legenda miłości, zwiastowania" 19 .

Traktowanie religii Jezusa jako zapisu, co prawda szlachetnych i pożytecz-

16 Wyraźnie to widać na przykładzie święta św. Stanisława, które w roku 1882 zostało skasowane przez carskie władze. Młodzież gimnazjalna i studenci odpowiedzieli na to bojkotem szkół i uczelni. Wśród nich byli wolnomyśliciele i socjaliści, albowiem święto to powszechnie uważano za narodowe; zob. „Głos” (Lwów) 5 IV $1912 \mathrm{nr} 78$.

17 „Czerwony Sztandar” 25 XII 1905 nr 29; zob. też: J. M a r chle w s ki, Pisma wybrane, Warszawa 1952, s. 74.

18 „Głos” (Lwów) 3 XI 1906 nr 42.

19 Podczas spotkań robotniczych wyjaśniano to w sposób jasny i klarowny. „Nasze pamiątkizwracal się do krawców I. Daszyński podczas zebrania 25 I 1897 - które obchodzimy, np. Boże Narodzenie, nie są niczym innym tylko zabobonem, podobnie jak u Żydów Pascha” (WÄP Kraków: StGrKr 23/1897). 
nych dla ludzi, ale jedynie legend i baśni, było typowe dla całego polskiego socjalizmu. Nie tylko zresztą polskiego. Pod tym względem bowiem socjaliści wcale nie byli oryginalni, raczej typowi dla tej epoki kultu rozumu, kwestionującej nie tylko boskość, lecz także historyczność Jezusa ${ }^{20}$.

Podobny efekt, tj. zachwianie zaufania do religijnej wykładni świąt mogło przynieść podważanie ich chrześcijańskiej etymologii. Przedstawiano więc dowody włączenia przez Kościół do swojej obrzędowości świątecznej pogańskich, starosłowiańskich symboli i zwyczajów. Swięta wiosny, lata czy zimy, podczas których to ongiś lud się weselił oraz składał ofiary i hołdy naturze, zostały zastąpione przez święta chrześcijańskie.

Nawet prasa informacyjna partii socjalistycznych nie była wolna od rozważań na ten temat i to nierzadko szczególowych. Z okazji najbardziej uroczystego i rodzinnego święta chrześcijańskiego - Bożego Narodzenia, m. in. stale podkreślano, iż ono nawiązuje do pogańskiej uroczystości przesilenia dni $\mathrm{z}$ nocą. „Dawno, dawno przed narodzeniem Nazarejczyka dni końcowe grudnia dla wszystkich ludzi sfery umiarkowanej były dniami radości i świętem nadziei"21. Wieczerza wigilijna połączona z wróżbami z kłosów i śpiewaniem kolęd jest starodawnym obrzędem pogańskim „przerobionym na chrześcijański z pieśni na cześć bogini Kolady"22.

Podobnie i święto zmartwychwstania ma bardzo starą tradycję, datującą się jeszcze z czasów antycznych. W dziejach ludzkości, ukrzyżowanie i zmartwychwstanie są tradycyjnym odwiecznym motywem, wprowadzonym tylko do religii Jezusa - powiadali socjaliści. Chrześcijańska Wielkanoc to święto radości, triumfu i spełnienia obietnic, tak jak pogańskie gody w czasie których świętuje się śmierć Marzanny ${ }^{23}$. Również święto Zielonych Świątek nie jest pomysłem chrześcijaństwa, lecz ,jest dziełem samej natury i datuje się od wieków. Wszystko co widzisz i co ciebie otacza, jest dziełem przyrody wraz z twoim dziełem, bez twojej pracy cała przyroda byłaby czczą i nic nie wartą"24.

Uwagę partii socjalistycznych zwłaszcza działających legalnie, PPSD i PPSzp, w nie mniejszym stopniu niż te kwestie zaprzątały sprawy praktyczne; sposób wykorzystania wolnego czasu w święta. Poczynając od lat dziewięćdziesiątych najpierw nieśmiało, później coraz bardziej zdecydowanie socjaliści galicyjscy i zaboru pruskiego zaczęli propagować swój własny sposób spędzania świąt. Święta powinny być - przekonywali - czasem godziwej rozrywki i odpoczynku wśród rodziny, przyjaciól i współtowarzyszy pracy. Miały być w większym stopniu niż niedziele — dniami przeznaczonymi do refleksji i zadumy na temat spraw, które interesowały społeczność robotniczą. Tematów do

${ }^{20}$ Dla okresu międzywojennego zob.: J. B og u cki, Boże Narodzenie, Berlin 1931, s. 14.

21 "Czerwony Sztandar” 25 XII $1905 \mathrm{nr} 29$.

22 [' $\mathrm{Cza}$ k i Franciszek] Mł o t Franciszek, Worek Judaszów, czyli rzecz o klerykalizmie, Warszawa 1908, s. 9; zob. też „Naprzód” 25 XII $1901 \mathrm{nr} 354$.

${ }_{23}$ Zob. m. in. J. Marchlewski, Pisma..., s. 298.

24 „Gazeta Robotnicza” 23 V $1896 \mathrm{nr} 21$. 
rozważań dostarczała prasa i periodyki PPSD i PPSzp: obowiązki wobec organizacji partyjnej, metody rekrutacji nowych czytelników i członków partii, sposób powiększenia funduszy partyjnych ${ }^{25}$. „Życzymy Wesołych Swiąt” pisała „Gazeta Robotnicza”. W dniach świąt pamiętać należy o przykazaniu wszystkich socjalistów: powiększaj szeregi uświadomionej klasowo armii proletariatu... Niechaj nikt nie zaniedba nadarzającej się okazji i podczas świąt gorąco agituje w kole krewnych, znajomych i przyjaciół na rzecz „Gazety Robotniczej" 26

Członkowie PPSD, a w czasie rewolucji również PPS, PPS-Frakcji Rewolucyjnej i PPS-Lewicy, w przeddzień świąt wzywali brać robotniczą do rezygnacji $\mathrm{z}$ alkoholu ${ }^{27}$. PPSD organizowała nawet specjalne akcje antyalkoholowe, wydawała okolicznościowe ilustrowane kartki, poruszała ten temat $\mathrm{w}$ prasie. „Dużo niestety mamy tradycji, które należy zaniechać. Do nich należy tradycyjne picie. Chrzciny obchodzi się piciem, wesele piciem, śmierć stypą i znów picie. Jeśli zwalczamy tradycyjny u nas klerykalizm, to musimy też zwalczać tradycyjne picie. SPD zdobyła sobie przez bojkot wódki uznanie wszystkich. Od dziś nie pijem — powinno być hasłem każdego. Największą szkodę wrogom naszym wyrządzamy przez bojkot alkoholu podczas świąt"28.

Socjaliści polscy nie wypowiadali się bliżej na temat właściwego, najstosowniejszego dla członków partii, ich zwolenników i sympatyków sposobu spędzania świąt. Trudno doczytać się z tych dość ogólnikowych zaleceń i wstępnych propozycji jakiejś wyraźniejszej koncepcji, zwłaszcza w odniesieniu do życia prywatnego. Ta sfera była regulowana indywidualnie. Jak wynika z przekazów pamiętnikarskich socjaliści - wolnomyśliciele nadawali praktykom i świętom dorocznym, o ile w ogóle je świętowali, sens laicki. Obchodzili zatem Wigilię Bożego Narodzenia, łamali się opłatkiem, niekiedy chlebem, a w Wielkanoc święcili pokarmy wielkanocne, ale czynności te dla nich miały znaczenie zwyczajowe, rodzinne - nie wyznaniowe.

Szczególną wagę przywiązywano do dzielenia się opłatkiem, który był świadectwem serdeczności, braterstwa i przyjaźni. Podobnie i wysyłanie opłatka w listach do przyjaciół i znajomych traktowali jako dowód pamięci i szacunku. „Wigilia jest jednym z tych świąt, z którymi związany jest zwyczaj życzenia sobie nawzajem wszystkiego najlepszego. Zwyczaj to dobry, bo ludziskom przyjemność sprawia - po cóż więc go odrzucać"29. Życzenia swoim czytelnikom i sympatykom składały też, dzieląc się opłatkiem, redakcje gazet PPSD

${ }^{25}$ CAKC mikrofilm 1050/2 k. 143.

26 "Gazeta Robotnicza" 3 VI $1911 \mathrm{nr} 64$.

27 '̌swięta - pisano - to godziny upijania się i objadania, a wszystko kończy się rozstrojem żołądka i bólem głowy; zob. „Naprzód” 24 XII 1904 nr 356; Czytelnia robotnicza, t. 2, Kraków 1905, s. $38 \mathrm{in}$.

28 „Prawo Ludu” 24 XII 1912 nr 51. Nawet w rodzinach zasymilowanych Żydów obchodzono uroczyście Boże Narodzenie i Wielkanoc; zob. M K a mińs k a, Scieżkami wspomnień, Warszawa 1960 , s. $183-183$

29 „Nowy Robotnik” 26 XII $1896 \mathrm{nr} 52$. 
i PPSzp, a podczas rewolucji i PPS. W okresie zaborów, szczególnie, dzielenie się opłatkiem stało się zwyczajem i wartością narodową. „Wilia bez opłatka mówiono - nie byłaby Polakowi wilią". Do tego świadomie nawiązywały partie socjalistyczne. „I ta wieczerza wigilijna i życzenia z opłatkiem są wyłącznie polskim obyczajem, a więc i my śpieszymy do Was, z życzeniami, w rocznicę narodzenia Boga - człowieka" 30 .

Na zakończenie Wigilii w domach polskich socjalistów - wolnomyślicieli śpiewano kolędy i to niekoniecznie rewolucyjne, czy to „dla tradycji czy ładnej melodii”. Zatem ani opłatek, kolędy, czy „święcone” praktykowane podczas świąt katolickich nie przesądzają jeszcze ani o gorliwości religijnej osób w tym uczestniczących ani o ich obojętności. Wszystko zależało od treści, które temu towarzyszyły, od znaczenia, które tym zwyczajom i symbolom się przypisywało.

Inny charakter miały „wigilie” $\mathrm{i}$,święcone” organizowane przez partie socjalistyczne dla swoich członków i sympatyków. Urządzali je już pierwsi polscy socjaliści działający w końcu lat siedemdziesiątych na ziemiach polskich zaboru rosyjskiego ${ }^{31}$. Spotkania te $z$ natury rzeczy, musiały mieć charakter konspiracyjny. W obu pozostałych zaborach mogły się odbywać i odbywały się legalnie. Partie i organizacje socjalistyczne traktowały je jako dogodną okazję do wzajemnego poznania się robotników i lepszego zaznajomienia się z ich programem.

Socjaliści, urządzając „wigilie” i ,święcone”, nawiązali do cechowych wzorów życia świątecznego, do tradycyjnego cechowego „opłatka” i „święconego". Tradycje te miały wpływ na szybką akceptację przez robotników i rzemieślników, znajdujących się w kręgu oddziaływania partii socjalistycznych, ich „wiligii” i „święconego”. Podobnie i organizacje katolickie oraz zrzeszające członków Narodowego Związku Robotniczego i Narodowego Stowarzyszenia Robotniczego, do tego nawiązywały, z tym, iż szczególną uwagę przywiązywały do ceremoniału religijnego.

Do tych samych wzorów sięgali również fabrykanci, organizując dla robotników świąteczne spotkania. Centralnym punktem było przemówienie właściciela lub któregoś z dyrektorów. Słynne m. in. były tzw. „dittrichowskie gwiazdki" w Żyrardowie, ogranizowal je również Cegielski w Poznaniu, Zieleniewski w Krakowie, Rudzki, Konrad i Jarnuszkiewicz w Warszawie ${ }^{32}$. W zaborze rosyjskim konspiracyjne ,wilie” narodowe organizowała endecja. Najbardziej znaną urządziła w roku 1898, kiedy to na wezwanie Ligi Narodowej, do War-

30 „Nowy Robotnik” 20 XII 1894 nr 25.

31 W. Ga w roń sk i, Wspomnienia z okresu walki z caratem, „Niepodległość” 19:1939 s. 48.

32 We Francji pracodawcy i pracobiorcy spotykali się przy drzewkach bożonarodzeniowych. Koszty ponosili właściciele; zob. S. B on n e t, L'homme du fer, $1889-1930$, Nancy-Metz 1976, s. 84 . 
szawy, z okazji odsłonięcia pomnika A. Mickiewicza przyjechali z całego kraju przedstawiciele środowisk robotniczych, inteligenckich i chłopskich ${ }^{33}$.

W prasie legalnych partii socjalistycznych, PPSD i PPSzp pojawiły się zaproszenia i zawiadomienia o mających mieć miejsce uroczystościach, które różnie nazywano: „wilie”, „boże narodzenie”, ,gody”, „wielka uroczystość godów”, „Boże Narodzenie”. Pojawiły się informacje o czasie i miejscu takich spotkań, często z ich szczegółowym programem, nierzadko też notatką, iż właśnie tym razem przygotowano zupełnie nowy atrakcyjny program o walorach widowiskowych i poznawczych. W swoim założeniu były to przedsięwzięcia od początku do końca pozbawione treści religijnych ${ }^{34}$.

Spotkania świąteczne PPSD oraz PPSzp rozpoczynały zazwyczaj okolicznościowe przemówienia, w których nie brakowało cytatów ewangelicznych uzasadniających potrzebę walki pracy z kapitałem; dalej uczestnicy mogli wysłuchać deklamacji poezji socjalistycznej, obejrzeć nawet specjalne widowiska teatralne oraz wziąć udział w śpiewie pieśni rewolucyjnych (kolędy robotnicze $)^{35}$. Coraz częściej „wilie” i „święcone” kończyły zabawy taneczne.

Spotkania te były dobrą okazją do propagowania idei socjalistycznych oraz integracji środowisk robotniczych. Natomiast nie miały na celu tworzenia nowej, alternatywnej obrzędowości świeckiej, choćby z tego powodu, iż zazwyczaj nie były zwoływane $\mathrm{w}$ dni świąteczne. Jedynie sporadycznie i to dopiero w ostatnich kilku latach poprzedzających wybuch I wojny światowej w Galicji i w zaborze pruskim, w drugi dzień Bożego Narodzenia i Wielkanocy organizowano uroczyste spotkania połączone $\mathrm{z}$ zabawą taneczną i występami amatorskich zespołów teatralnych PPSD lub PPS zaboru pruskiego. Uroczystości te były przyjmowane bardzo krytycznie przez środowiska narodowe, zachowawcze i katolicko-społeczne, co być może miało również wpływ na ich powolną akceptację przez kręgi robotnicze związane z socjalistami. „Socjaliści pokazali jaskrawo, że przepisy kościoła katolickiego obchodzą ich tyle, co psa piąta noga - jest to grzech śmiertelny urządzać zabawę w Wielkanoc"36.

Za pośrednictwem prasy katolickiej, ambony i konfesjonału na temat świąt socjalistów docierały do wiernych opinie, które mogły wywoływać grozę i oburzenie na tych, co je organizują. Socjaliści podczas tych uroczystości mieli łamać przykazania, zalecenia i nakazy Kościoła, jeść zakazane mięsne potrawy w czasie wigilii, czy w Wielkim Tygodniu ${ }^{37}$. Mówiono i pisano o profanowaniu

${ }^{33}$ S. Kozick i, Historia Ligi Narodowej (okres 1887 - 1907), Londyn 1964, s. 349.

34 „Równość” 2 XII 1898 nr 34; „Równość” 15 XII 1900 nr 35.

${ }^{35}$ CAKC mikrofilm 1248/2 k. 13 (1899).

36 „Gazeta Ludowa” 21 IV 1911 nr 48; „Gazeta Robotnicza”, 27 IV 1911 nr 49.

${ }^{37}$ F. B a ch ow s k i, Swiatto do „Latarni”, Kraków 1901, 31 -32. Istotną rolę w wytworzeniu się tych opinii odegrały wieści, które docierały do Polski z krajów Europy zachodniej, m. in. na temat tzw. "Saint-vendredi”, tj. „tłustego wielkiego piątku”, podczas którego socjaliści, anarchiści, wolnomyśliciele wraz z rodzinami spożywali potrawy mięsne. Traktowali to jako manifestacyjne uwolnienie się od „przesądów religijnych”. Odpowiedź polskich socjalistów na te zarzuty była m. in. zawarta w popularnej broszurze Zygmunta Klemensiewicza pt. Czy socjaliści jedzq w wielkim 
„świętych prawideł katolickich”. Często używane słowo „profanacja” miało być skuteczną barierą chroniącą wierzących przed zgubnymi ideami socjalistów.

Mimo jednak tych opinii coraz to nowe kręgi socjalistów - robotników urządzały swoje święta ${ }^{38}$. Socjaliści z PPSD i PPS zaboru pruskiego zapraszali na nie rodziny, znajomych, krewnych, ludzi często dalekich od socjalizmu. Czynili tak również w tym celu, by naocznie mogli się oni przekonać, iż zasłyszane opinie na temat „świąt socjalistycznych” dalekie są od prawdy. „A kiedy chórem podług muzyki tow. Golejewskiego zaśpiewano [W Berlinie w.1896 r.] Kolędę robotniczq i $W$ żtobie leży, zatenczas i ci, którzy przybyli tylko z przyjacielstwa, poznali w żywiole polsko-robotniczym nowe odrodzenie i duszą i sercem przylgnęli do niego. Najbardziej to się uwidoczniło u niektórych krewnych braci socjalistów, którzy z dalekich Prus i Poznańskiego przybyli na święta do Berlina, aby swoich krewnych nawrócić od zgubnej drogi socjalizmu [...]. Tak niejeden z tych uczestników, który przybył jako Szaweł, powracał do swojej ojczyzny jako nawrócony Pawel" 39 .

W wielkie święta doroczne PPSD i PPS zaboru pruskiego nie urządzały publicznych manifestacji i zgromadzeń. Dla wierzących, święta, zwłaszcza te najbardziej uroczyste były czymś szczególnym i wyjątkowym. Organizowanie wówczas imprez publicznych musiałoby ich dotknąć i urazić. Jedynie podczas rewolucji 1905/07 r. PPS i SDKPiL urządzały w święta wiece i manifestacje publiczne a nawet rozpoczynały strajki, jak choćby 25 grudnia 1905 r., kiedy to w Królestwie zaczął się strajk powszechny. Wywołało to istną burzę w polskim społeczeństwie; gromy padały na socjalistów za naigrywanie się z Bożego Narodzenia. „Jaka to niegodziwość rozpoczynać strajk w święto. Rzeczywiście jaka niegodziwość... Gdy zbliża się wielka i święta walka, oni o wieczerzę się troszczą, o spokojne trawienie" 40 .

W miarę możliwości „wilie” $i$ „święcone” organizowali sobie również socjaliści z zaboru rosyjskiego, członkowie Proletariatu, SDKPiL, PPS znajdujący się na zesłaniu lub w więzieniu ${ }^{41}$. Dni te we wspomnieniach Sybiraków i więźniów należały do szczególnie ważnych. Starano się, aby były to uroczystości

poście kietbasę? Została ona również wydana przez Związek Socjalistów Polskich w Stanach Zjednoczonych.

38 Skala przedsięwzieć socjalistów galicyjskich w porównaniu do francuskich czy belgijskich była skromna. Podczas socjalistycznych Noël we Francji czy w Belgii brało udział po kilkaset i więcej osób. Wejście płatne. Czas trwania kilku godzin, teatr, widowiska, konkursy na utwory muzyczne, turnieje, w tym poetyckie, skecze, krótkie utwory dramatyczne, jednoaktówki. Były to święta, jak je nazywano, nowej idei, wspólnoty idei, które pociągają ludzkość w kierunku grupowania się w uniwersalnej solidarności. Święta triumfu światła i życia nad śmiercią i pogardą; zob. „La Guerre Sociale" 8 I $1907 \mathrm{nr}$ 2; A r o n P., Les écrivains belges et le socialisme (1880 - 1913), Bruxelles 1985 , s. 55.

39 „Gazeta Robotnicza” 4 I 1896 nr 1. We Francji już w latach osiemdziesiątych organizowano „wigilie”, ale w dzień wigilijny (24 XII); „Le Prolétaire” 23 XII $1882 \mathrm{nr} 221$.

40 „Gazeta Robotnicza” (Warszawa) 25 XII 1905 nr 29.

41 Zazwyczaj władze więzienne wyrażały zgodę na tego rodzaju spotkania. 
prawdziwie rodzinne, $\mathrm{z}$ udziałem socjalistów innych narodowości dzielących ten sam tułaczy czy więzienny los. W więzieniach na te spotkania zapraszano cieszących się dobrą opinią pracowników służby więziennej.

$\mathrm{Na}$ święta znajomi i rodziny z kraju przysyłali życzenia i paczki. Również więźniowie i zesłańcy słali do swoich bliskich i przyjaciół życzenia świąteczne. Jeden z więźniów pisał do Witolda Jodki-Narkiewicza: „prosimy Pana Boga, aby dał Mu moc i szczęście do dalszego kierowania świętą sprawą oświecenia ludzi [...] dzięki Panu spotykamy wielkie święto, polskim obyczajem łamiąc się opłatkiem"42.

Na wspólne świąteczne spotkania każdy przynosił ze sobą to, co miał stosownego. „Całą grupą zesłańców szykowaliśmy się do świąt Bożego Narodzenia - wspomina Ignacy Lisowski. Zgodnie $\mathrm{z}$ tradycją chcieliśmy upiec jakieś strucle, przyrządzić trochę świeżej ryby, no i zdobyć jakąś wędlinę. Niestety nie hodują tutaj świń [...]. Mieliśmy za to wspaniałą jodłę jako choinkę, a jej udekorowaniem zajął się Moszczyński. Były więc papierowe anioły, Mikołaj $\mathrm{z}$ dużą brodą, gwiazda i śnieg z bibułki. Brakło tylko świeczek [...]. Aż tu w ostatnim dniu przed Wigilią przyjeżdża poczta i o dziwo - przywozi nam opłatki, a Moszczyński dostaje pięciofuntową kiełbasę i świeczki. Trudno opisać naszą radość [...]. Nie obyło się oczywiście bez kolęd ${ }^{43}$.

Z okazji świąt składano sobie wzajemnie życzenia. Gustaw Daniłowski wspomina, że „przy tradycyjnym opłatku życzono sobie latwego skonania, wygodnych kajdanków, pomyślnej podróży na północ, szybkiego uwolnienia, co komu w perspektywie wypadało" 44 . Słowa Daniłowskiego są interesującym przykładem obyczajowości rewolucjonistów, którzy z humorem przerabiali tradycyjne życzenia wigilijne.

Podziały partyjne, już bardzo wyraźne na początku wieku nie przeszkadzały w urządzaniu wspólnych świąt, raz ze względu na charakter chwili, dwa ze względu na okoliczności. „W Wigilię Bożego Narodzenia - ów tradycyjny dzień rodzinnego święta w kraju - pisał z więzienia w Krasnojarsku Wacław Koral - wszyscy Polacy, esdecy, pepesowcy i proletariatczycy skupili się razem - razem myślą i duchem — przenieśli się pod rodzinne strzechy"45. Swięta kończyły recytacje poezji rewolucyjnej i wspólny śpiew. Podczas tych spotkań przebiegających zazwyczaj w atmosferze wzajemnej serdeczności i przyjaźni, zdarzały się jednak sytuacje konfliktowe, jak choćby z powodu repertuaru

42 CAKC mikrofilm 11/67/7 k. 86. Korespondencja z grudnia 1904 r.; podpisał w ,imieniu towarzyszy" Józef Kozłowski.

${ }_{43}$ J. Li s o w s k i, Etapy. Wspomnienia działacza SDKPiL, Warszawa, 1975, s. 159; zob. też P. Modrowski, $W X$ Pawilonie, [w:] W pracy $i w$ walce. Wspomnienia robotników warszawskich $z$ przełomu XIX i XX wieku, Warszawa 1970, s. 142; A. Ki eł za, Na Pawiaku, tamże, s. 84.

${ }^{44} \mathrm{G}$. D a nił ow s ki, Wspomnienia więzienne z Pawiaka, Lwów 1908, s. 84.

45 W. Ko r a l, Przez partie, zwiqzki, więzienia i Sybir [...] Wspomnienia drukarza z dziatalności w ruchu socjalistycznym $i$ zawodowym $1898-1928$, Warszawa 1933, s. 117. 
wykonywanych pieśni. Członkowie SDKPiL wyrażali swoje niezadowolenie z pieśni patriotycznych śpiewanych przez socjalistów z PPS ${ }^{46}$.

Swięta Bożego Narodzenia i Wielkanocy polskich społeczności na zesłaniu i w więzieniu organizowane były ku pokrzepieniu serc, $w$ walce $\mathrm{z}$ własną słabością, marazmem i pesymizmem. Łączyły się one nie tylko $\mathrm{z}$ życzeniami religijnymi i własnymi potrzebami, lecz także, a niekiedy przede wszystkim z potrzebą intensywnego, emocjonalnie wzruszającego obcowania ze swym środowiskiem. W szarzyźnie życia Sybiraków i więźniów miały ważne znaczenia. W tych spotkaniach świątecznych momenty religijne, motywy narodowe i ludowe były razem splecione, z nową obyczajowością rewolucjonistów. Były okazją by inaczej spędzić ten jeden czy dwa wieczory, oderwać się od biedy sybirackiego zesłania i więziennego wiktu.

$\mathrm{Na}$ zesłaniu i w więzieniu rodziły się nowe wzory wspólnego świętowania i zwyczaje, które później były przenoszone do własnych środowisk i rodzin. Lecz nie można tego traktować jako działań programowo antykatolickich, skierowanych przeciw dotychczasowym treściom i obrzędom świątecznym. Więzienne czy sybirackie święta nie miały na celu ustanowienia świeckiej obrzędowości, która stopniowo, w sposób zaplanowany miałaby zająć miejsce religijnej.

W kraju pierwszą, znaną próbą zastąpienia dotychczasowych obrzędów i rytuałów religijnych, nowymi, laickimi wiążemy z nazwiskiem Jana Hempla, znanego już wówczas religioznawcy, sympatyka PPS-Lewicy, po wojnie członka KPP. W ostatnich latach przed wybuchem I wojny światowej zainicjował on stworzenie religii narodowej, „piastowej”, co swój teoretyczno-doktrynalny wyraz znalazło w jego „Kazaniach Piastowskich” i „Kazaniach Polskich”. Prace nad nową religią podsunęły mu myśl urządzenia socjalnej „wilii słowiańskiej”, „wigilii piastowskiej”. Po raz pierwszy została ona zorganizowana w Lublinie w roku $1910^{47}$. W pierwszej i w kilku kolejnych „wiliach słowianskich", w mieszkaniach prywatnych, brało udział po kilkadziesiąt osób z kręgu lubelskiej PPS-Lewicy, socjalistycznych środowisk młodzieżowych i wolnomyślicielskich. Wśród organizatorów znajdował się m. in. Bolesław Bierut.

W czasie „wilii słowiańskiej” stoły nakrywano białym obrusem, a przy każdym nakryciu układano po kilka kłosów żyta. Uroczystość rozpoczynał Hempel mówiąc o znaczeniu święta - przesilenia dnia z nocą, święta związanego $\mathrm{z}$ odwiecznym kultem ognia. Tej nocy podkreślał, w wielu kultach rodził się bóg. Następnie jeden z uczestników odczytywał fragmenty z „Kazań Piastowych", po czym łamano się chlebem. W czasie wieczerzy spożywano chleb,

\footnotetext{
${ }^{46}$ Z. Kruszews k a, Życie i muzyka więzienia (1906-1907), „Niepodleglość” 15:1937s. 88.

${ }^{47} \mathrm{Nie}$ był to pomysł zupełnie oryginalny, albowiem na początku lat czterdziestych XIX $\mathrm{w}$. przemyśliwał o czymś podobnym Edward Dembowski. Warto też wspomnieć, iż w 1918 - 1939 radykalne kręgi ludowców (,Wici”), propagowały kult bogów słowiańskich.
} 
owoce, potrawy jarskie oraz używano napoi bezalkoholowych ${ }^{48}$. Po wieczerzy odczytywano zbiorowo, na głosy, scenę wywożenia patriotów na Sybir z Mickiewiczowskich „Dziadów”. „Wigilię” kończyły deklamacje poezji rewolucyjnej i śpiew pieśni socjalistycznych. Józef Dominko pisał, iż „wszyscy mieliśmy łzy w oczach. Tak nas nastrajała nie tylko poezja, ale i tajemniczość i niezwykłość [...] samej uroczystości. Ludzie w ogóle, a młodzież w szczególności potrzebowała takich głębszych przeżyć" 49 . J. Hempel troszczył się, by uroczystość oddziaływała nie tylko na emocje i uczucia, ale starał się by miała też wpływ na umysły uczestników. Życzył sobie, by uczestnik znalazł racjonalne argumenty za taką wersją świętowania. Trwałość, „wilii słowiańskiej”, gdyż również w latach międzywojennych była urządzana, dowodzi, iż mu się to uda$10^{50}$.

Poza krajem podobne uroczystości organizowała od roku 1900 sekcja paryska Polskiej Ligi Wolnej Myśli, wzorując się na podobnych zainicjowanych po roku 1901 przez gazetę „La Raison” w Paryżu. Brało w niej udział po kilkuset uczestników, w tym liczna grupa polskich socjalistów. Po raz pierwszy tzw. Kolęda Wolności (Noël Humaine) została zorganizowana w roku 1906 w dzień wigilijny Bożego Narodzenia. Program wypełniły pieśni, przemówienia, muzyka i poezja. W ten sposób czczono przyszłe „Wolne Człowieczeństwo”. Zebranych przywitał i wygłosił okolicznościowe przemówienie J. Zieliński. „,Trzeba się liczyć - mówił - z ludzką naturą, z psychologią ludzi. Nie można im świąt zabierać [...]. Trzeba też w dni, które od wieków były dla ludzi pewnym symbolem, urządzać świeckie wolnomyślne uroczystości [...] zaśpiewać ale nie Kantyczkę, nie pod boską opiekę, lecz hymn buntu, pieśń prawdziwej wolności. Po raz pierwszy my wolnomyśliciele - my ateusze — na miejsce dawnych pogańskich saturnalij, na miejsce obłudnych chrześcijańskich świąt narodzin Jezusa — my chcemy obchodzić w to przedednie wiosny Narodziny Ludzkości, Narodziny wolności”. Dalej „dzisiejszy dzień nie jest to rocznica urodzin jakiegoś Jezusa, odkupiciela (...). Ale od wieków, niemal od świata istnienia, jest to święto młodości, święto narodzin nowych nadziei" ${ }^{51}$.

Wieści o poszukiwaniach nowej formuły wigilii Bożego Narodzenia przez polskich wolnomyślicieli w Paryżu, docierały do środowisk inteligenckich w kraju, czego potwierdzeniem są wzmianki w pamiętnikach. Natomiast do środowisk robotniczych dotarły wieści na temat zupełnie nowej robotniczej wi-

48 W. P a pie w sk a, Jan Hempel. Wspomnienia siostry, Warszawa 1958, s. 51.

$49 \mathrm{~J}$. D o m in k o, Z minionych lat. Wspomnienia dziatacza-spótdzielcy z okresu pracy na terenie Lublina, Warszawa 1945, s. 14.

${ }^{50}$ Tamże, s. 19 nn. Po I wojnie światowej, w dzień przesilenia słonecznego (24 XII), organizowano w Lublinie wigilie spółdzielcze. Uroczystość rozpoczynała się 24 grudnia o godz. $24^{\circ o}$, po oficjalnych sprawozdaniach z tego, co zrobiono w bieżącym roku słonecznym, i rozważaniu tego, co się zamierza w przyszłości, następowała wieczerza, a po niej zabawa taneczna.

51 WAP Kraków: SKKr 1211 (sprawozdanie Polskiej Ligi Wolnej Myśli, przemówiele J. Zielińskiego z 25 XII 1906 r.); zob. L. Pé r ou as, Refus d'une religion en Limousin rural $1880-1940$, Paris 1985, s. 170. 
gilii i Bożego Narodzenia, zorganizowanych w związku ze strajkiem robotników niemieckich w saskiej Crimnitzschau. Trwający 17 tygodni strajk 7 tysięcy włókniarzy przeciągnął się aż na okres świąt roku 1903. Strajkujący postanowili świętować gromadnie i publicznie, ale nie uzyskali zgody ani pastorów ewangelickich ani księży katolickich. W odpowiedzi wielu robotników wystąpiło z kościołów. Wbrew duchownym, jak pisał „Czerwony Sztandar”, w dzień „bożego narodzenia” robotnicy obchodzić będą „święto własnego boga — socjalizmu" 52 .

Wieczorem w dzień wigilijny odbyła się pierwsza tak masowa impreza pozbawiona zupełnie treści religijnych. Zapłonęły świeczki na „Bożych drzewkach", wysłuchano przemówień, dzielono się chlebem podczas składania życzeń. Po wigilii dzieci obdarowano prezentami przysłanymi w paczkach z całych Niemiec. „Gdy zwyczajem chrześcijańskim zapytano dzieci: A czy wiecie, kto was tymi cudnymi rzeczami obdarzył? - odpowiedziały jak zwykle Dzieciątko Jezus. Lecz gdy je zapytano dalej: A czy wiecie Wy, kto był dla Was tym Dzieciątkiem Jezus? — odpowiedziały chórem: Wiemy! Niemieccy robotnicy!"53.

Podobnych imprez, jak w Crimnitzschau, w Polsce nie urządzano, zresztą w Niemczech i w Europie zachodniej w owym czasie należały do rzadkości. W skali masowej miały jedynie miejsce podczas Wiosny Ludów we Francji, ale w latach późniejszych już tylko sporadycznie były organizowane ${ }^{54}$. We Francji, Belgii czy Niemczech również kameralne „nowe wilie” organizowane przez partie socjalistyczne, anarchistów i wolnomyślicieli miały niewielki zasięg społeczny. Próby tworzenia w miejsce Wigilii Bożego Narodzenia zupełnie nowych, zakończyło się jedynie połowicznym sukcesem. Zdaniem badaczy francuskich i belgijskich tylko mniejszość socjalistów je zaakceptowała ${ }^{55}$.

W Polsce, poza Lublinem, nie spotkaliśmy innych podobnych przykładów. „Nowe wigilie” zbyt gwałtownie zrywały z obowiązującym od wieków tradycyjnym ceremoniałem i obrzędowością by mogły liczyć na szersze zrozumienie i akceptację. Ponadto, jak można sądzić, spodziewane korzyści z ewentualnych eksperymentów nie były ani tak oczywiste, ani tak wielkie.

Zgodnie z kalendarzem liturgicznym kolejnymi po Wielkanocy ważnymi świętami katolickimi są Zielone Świątki i Wigilia św. Jana. Wielkanoc rozpoczynała sezon spacerów po mieście i wieczornych spotkań towarzyskich, są-

52 „Czerwony Sztandar”, dod. do nr 13 I 1904.

53 "Głos Robotniczy" 1 I 1904 nr 1.

54 Apele francuskich partii socjalistycznych, również belgijskiej i szwajcarskiej, o organizowanie laickich świąt, zwłaszcza podczas Bożego Narodzenia i Wielkanocy, nie znalazły szerszego zrozumienia chyba dlatego, że „nowe” propozycje niejednokrotnie były jedynie gorszym, mniej udanym wydaniem „starych”; zob. L. Pé ro u as, jw., s. 171; A. Le s s e r re, Les origines du socialisme dans le canton de Vaud, [w:] Melanges offerts à G. Jacquemyns, Bruxelles 1968, s. 236; E. V a ndervelde, Socjalizm a religia, Kraków 1908, s. 32.

${ }^{55} \mathrm{R}$. V a n de n bu s s c h e, Libre pensée et libres penseurs dans le Nord Sous la III République, [w:] Libre pensée et religion laique en France, Strasbourg 1980, s. 174; L. Pé r o u a s, jw., s. 170. 
siedzkich, a Zielone Swiątki majówek i zabaw ludowych, festynów. W skali masowej uczestniczyli w nich robotnicy i to nie tylko większych miast polskich. Kultywowali oni zabawy i świąteczne formy wypoczynku tradycyjne dla mieszkańców miast. Robotnikom i rzemieślnikom kojarzyły się te święta nie tylko $\mathrm{z}$ uroczystymi nabożeństwami, odpustami, procesjami, lecz także z zabawą taneczną, muzyką i śpiewem.

Do tych zwyczajowych zachowań świątecznych włączyły się od początku lat osiemdziesiątych organizacje socjalistyczne, najpierw w zaborze rosyjskim, urządžając w Zielone Świątki i Wigilię św. Jana wycieczki poza miasto, połączone $\mathrm{z}$ zabawami tanecznymi, deklamacjami poezji i śpiewem pieśni rewolucyjnych. Wyjazdom poza miasto partie socjalistyczne próbowały nadać charakter zorganizowany oraz kierunek pożądany z punktu widzenia własnych interesów. „Winniśmy być zadowoleni - pisał Marchlewski - że możemy je (Zielone Świątki) świętować na nasz sposób ${ }^{56}$.

W czerwcową noc świętojańską (Wigilia św. Jana) do corocznego zwyczaju sięgającego jeszcze czasów pogańskich, należało też spuszczanie wianków na wodę, fajerwerki, strzelanie na wiwat, korowody udekorowanych powozów. Zwyczaje „wianków” partie socjalistyczne wykorzystały do propagowania swojego programu i manifestacji politycznych. Pierwszą taką akcję w dziejach socjalizmu w Polsce zorganizowała tzw. stara PPS w nocy z 23 na 24 czerwca 1893 r. w Warszawie. Wtedy to na Wisłę spuszczono wianek wraz z umocowaną doń piramidą zaopatrzoną w napisy rewolucyjne: „Niech żyje Polska socjalistyczna!”. „Precz z caratem”, „Robotnicy wszystkich krajów łączcie się”. Niestety impreza się nie udała, organizatorzy zostali nakryci na gorącym uczynku i aresztowani, gdyż w przygotowaniach brał udział groźny prowokator Władysław Sidorek ${ }^{57}$.

Na kolejne, tym razem udane „wianki socjalistyczne” w zaborze rosyjskim i to również na Wiśle trzeba było czekać aż do roku 1904. Podczas rewolucji parokrotnie jeszcze PPS i SDKPiL urządzaly takie manifestacje na wodzie (Wisła, Warta, Prosna) z czerwonymi sztandarami i odpowiednimi napisami ${ }^{58}$. Robiły one niemałe wrażenie zwłaszcza, że inne organizacje społeczne, kulturalne, które wcześniej corocznie urządzały „wianki”, w okresie rewolucji $\mathrm{z}$ tego zrezygnowały.

W zaborze austriackim własne „wianki” organizowała PPSD m. in. na Wiśle w Krakowie i na Olzie w Cieszynie. Korzystając z dogodnych warunków politycznych nie ograniczała się do puszczania wianków na wodzie, ale tego dnia urządzała całodniowe imprezy, przygotowane przez komitety oparte na szer-

56 J. Marchlewski, Pisma..., s. 74.

57 A. Próchnik, U wstęu do dziejów Polskiej Partii Socjalistycznej (Sprawa „Wianków”), [w:] Kronika Ruchu rewolucyjnego w Polsce, t. 3, Kraków 1937, s. 141 n.; CAKC t. os. 9337 (Leopold Dobraczyński).

58 WAP Łódź: TGG Kal. IV - 32/1907 k. 54 (naczelnik pow. łęczyckiego i kaliskiego). 
szej bazie politycznej i bez szyldu partyjnego. Dzięki temu brali w nich udział również robotnicy i rzemieślnicy niezorganizowani ${ }^{59}$.

Szczególny charakter miało doroczne święto zmarlych, obchodzone przez Kościół katolicki w dniu 1 (Wszystkich Świętych) i 2 listopada (Dzień Zaduszny). W warunkach Polski porozbiorowej stało się ono, zwłaszcza w większych miastach trzech zaborów uroczystością publiczną i narodową. W tych dniach bowiem gromadzono się przy grobach bohaterów powstań oraz Polaków szczególnie zasłużonych dla polskiej kultury i sztuki. Składano kwiaty, wieńce, śpiewano pieśni patriotyczne, niekiedy słuchano okolicznościowych płzemówień $^{60}$. Początkowo uroczystości te miały charakter spontaniczny, później zwłaszcza za sprawą Ligi Narodowej — zorganizowany.

Jedynie w Galicji takie przedsięwzięcia mogły się odbywać faktycznie bez przeszkód, w zaborze pruskim już z większymi trudnościami, natomiast w rosyjskim od początku były nielegalne. Obecni na cmentarzach mogli brać udział nie tylko w manifestacjach narodowych, lecz także w demonstracjach organizowanych przez socjalistów, którzy zbierali się przy grobach by oddać hołd zmarłym towarzyszom walki. Licznie gromadzono się zwłaszcza wokół mogił zbiorowych. W ten sposób dokumentowano istnienie ciągłości sprawy robotniczej i idei socjalistycznej. „Czcimy naszych zabitych, nie dla jakiejś „estetyki”, nie dla pięknego „gestu tragedii”, lecz dlatego, bo wiemy, że ciałami swojemi ochraniali tysiące żywych, bo czujemy się solidarni aż poza grób. Nie lamentujemy więc na grobach naszych zabitych i nie wzywamy gromów zaziemskich"61.

Po raz pierwszy w sposób manifestacyjny oddano hołd zmarłemu socjaliście w Dzień Zaduszny 2 listopada 1879 r. w Warszawie. Wówczas to robotnicy warszawscy, młodzież gimnazjalna, członkowie pierwszych kółek socjalistycznych udali się na Powązki na grób tragicznie zmarłego (zastrzelonego w X Pawilonie) młodego Józefa Bajtego „pierwszego męczennika za socjalistyczną sprawę" i zatknęli na jego grobie dwie flagi: czerwoną i biało-czerwoną ${ }^{62}$. Obecność tej drugiej jest dosyć zaskakująca, biorąc pod uwagę zdecydowanie negatywne nastawienie socjalistów pierwszej generacji do tradycji narodowej i idei niepodległościowej. Dotychczas flagi biało-czerwone umieszczano na grobach wybitnych Polaków, zmarłych powstańców i spiskowców.

Później, aż do lat dziewięćdziesiątych podobnych manifestacji na cmentarzach zaboru rosyjskiego nie urządzano, co najwyżej na grobach socjalistów męczenników i bohaterów zapalano świeczki i składano kwiaty. W miarę upływu lat robotnicy sami zaczęli odczuwać potrzebę publicznego zamanifestowania pamięci o zmarłych. Ponownie, po dłuższej przerwie, pojawili się w więk-

${ }^{59}$ Po zakończeniu I wojny światowej organizowano w Lublinie przez Komisję Kultury Proletariackiej PPS tzw. „świętojanki”; zob. J. Do m in k o, jw., s. 14.

${ }^{60}$ Zob. m. in. W. O pał e k, O Lwowie mojej młodości, Kraków [...] 1987, s. $174-17 \overline{5}$.

61 „Naprzód” 8 VI 1904 nr 154.

62 „Równość" XI 1879 nr 2. 
szej liczbie przy grobach swoich towarzyszy pracy w roku 1899 w Dąbrowie Górniczej i w Warszawie. W Dąbrowie górnicy, w tym i członkowie PPS, udali się na groby bezpośrednio po dziennej szychcie, z lampkami górniczymi w dłoniach. O demonstracji dąbrowskiej pisał S. A. Radek: „1 listopada odbył się w Dąbrowie uroczysty obchód drugiej rocznicy mordu popełnionego przez carat na robotnikach Huty Bankowej, o godz. $31 / 2$ po południu zebrali się na cmentarzu dąbrowskim robotnicy. Grób obsypano kwiatami, a na nim na krzyżu zawieszono wieniec cierniowy ubrany czerwonymi kwiatami, z następującym napisem na czerwonych wstęgach: „Pomordowanym ofiarom rządu carskiego - Robotnicy Dąbrowy i okolic"63.

„Socjalistyczne Zaduszki”, gdyż tak zaczęto nazywać manifestacje na grobach zmarłych socjalistów obchodzono w Warszawie na cmentarzu bródnowskim, który był tradycyjnym miejscem pochówku proletariatu. Robotnicy grupami obchodzili groby zmarłych towarzyszy pracy i śpiewali znane już im wówczas pieśni: „Czerwony Sztandar”, „Warszawiankę”, „Żegnaj nam żegnaj”. „Ludzie znajdujący się na cmentarzu otoczyli ogromnym pierścieniem śpiewających a spomiędzy tej zbitej masy ludzi płynęły dźwięki pieśni robotniczej, której echa rozlegały się daleko na całym cmentarzu. Później śpiewano jeszcze na grobach tow: Milewskiego i Ceryngiera... Do późnej nocy mogiła tow. Ledera była oblężona przez ciekawskich... ludzie zapalali świecie i czytali napis na wstęgach. Dopiero nazajutrz rano znikł wieniec z cmentarza" 64 .

W miarę zbliżania się rewolucji 1905/07 ilość cmentarzy, gdżie urządzano socjalistyczne „Zaduszki” szybko rosła, zwiększała się liczba manifestantów, coraz aktywniejsze w działalności przygotowawczej były partie robotnicze, PPS i SDKPiL. Demonstracje na grobach stały się istotnym wskaźnikiem dynamiki bojów klasowych i politycznych w zaborze rosyjskim a jednocześnie czynnikiem mobilizującym robotników do dalszej walki. W roku 1904 obok Warszawy i Zagłębia Dąbrowskiego, „Czerwone Zaduszki” odbyły się jeszcze w Łodzi, Wilnie, Radomiu, Częstochowie i Lublinie. Carskie władze (Gubernator von Nolken) zaniepokojone możliwością zorganizowania przez PPS i SDKPiL manifestacji w dniu 1 i 2 listopada tegoż roku wydały zarządzenie o ograniczeniu ruchu na cmentarzach. Mimo tych zabiegów manifestacje były udane a zdaniem i partii socjalistycznych i władz wywołały duże poruszenie wśród ludności.

W czasie rewolucji 1905/07 r. „socjalistyczne Zaduszki” urządzali również socjaldemokraci litewscy i łotewscy. W Windawie (Łotwa) nad mogiłą straconych w grudniu 1905 r. robotników, tamtejsi członkowie socjaldemokracji łotwskiej ustawili krzyż i pomalowali go na kolor czerony. Policja carska krzyża nie usunęła, ale kilkakrotnie musiała go zamalowywać na czarno.

${ }^{63}$ S. Ra de k, Rewolucja w Zagtębiu Dąbrowskim 1894-1905 - 1914, Sosnowiec 1929, s. 33.

${ }^{64}$ Materiaty do historii PPS i ruchu rewolucyjnego w zaborze rosyjskim od roku 1899 do 1904, wyd. A. Malin owski, t. 2, Warszawa 1911, s. $140 \mathrm{nn}$. 
W latach dziewięćdziesiątych świadkami pierwszych manifestacji na grobach zmarłych socjalistów stali się również mieszkańcy Galicji. Policja nie interweniowała, inaczej niż w zaborze rosyjskim. Przedsięwzięcia te $\mathrm{z}$ reguły były dobrze przygotowane od strony organizacyjnej przez PPSD. Uczestniczyły w nich partyjne i związkowe poczty sztandarowe, a na cmentarzu i podczas pochodu na cmentarz oraz z powrotem chóry robotnicze śpiewały pieśni rewolucyjne i żałobne. W Galicji manifestacje przy grobach zmarłych towarzyszy organizowali też robotnicy żydowscy i ukraińscy.

Najrzadziej demonstracje tego rodzaju odbywały się w zaborze pruskim, raz z powodu słabości tamtejszego ruchu socjalistycznego a ponadto, gdyż nie było zbyt wielu okazji ku temu. Najliczniejsze manifestacje organizowano przy grobie Franciszka Morawskiego, leadera PPS zaboru pruskiego, zmarłego w roku 1906. W cztery lata później PPSzp wezwała członków partii do zbierania składek na granitowy pomnik, z płaskorzeźbą naturalnej wielkości na jego grobie w Katowicach ${ }^{65}$.

W roku 1911, w piątą rocznicę śmierci, na cmentarzu odbyło się uroczyste spotkanie robotników przy wzniesionym już pomniku. Z tej okazji PPSzp wydała też specjalne karty widokowe $\mathrm{z}$ nagrobkiem zmarlego - bohatera, męczennika za sprawę robotniczą. „Gazeta Robotnicza” tak o tym pisała: „Proletariat polski według swych skromnych sił wystawił mu pomnik, aby na zawsze świadczył o potężnym uczuciu wdzięczności świadomego ludu polskiego dla swego bojownika. Lecz najtrwalszy pomnik zbudujemy Morawskiemu i najgodniej uczcimy jego pamięć, jeżeli jego wzorem pracować będziemy nieustraszenie i wytrwale dla sprawy"66. Od brzozowego krzyża na grobie robotnika, do granitowego, imponującego pomnika — w tym się zawiera najkrótsza synteza tego co się dokonało w życiu robotników polskich i w ruchu socjalistycznym na przestrzeni kilkudziesięciu lat.

Od początku XX wieku coraz częściej manifestowano przy grobach i w innych terminach. O potrzebie pamięci o zmarłych przez cały rok, a nie tylko przez dzień lub dwa, pisał „Naprzód”: „Proletariusz nie tylko raz w roku, ale przez cały rok pamięta o swoich poległych, ciągle nosi w sercu pamięć o tych, co zginęli na pobojowisku pracy lub z nędzy i głodu, tych ofiar, które pochłonęły katastrofy kopalniane w Karwinie i Borysławiu tych, którzy polegli od kul żandarmskich na ulicach Lwowa i w Polskiej Ostrawie. W sercach proletariatu goreją dla nich żywsze i trwalsze ognie, niż te, które w dzień zaduszny przez kilka godzin błyszczą na cmentarzu" 67.

Najczęściej manifestacje przy grobach w różnych terminach urządzano w zaborze rosyjskim w okresie rewolucji 1905/07. Okazji nie brakowało: rocz-

65 W. Zi eliń ski, Franciszek Morawski 1847-1906, Katowice 1983, s. 18; „Gazeta Robotnicza" 24 II $1910 \mathrm{nr} 23$.

66 "Gazeta Robotnicza” 24 VI 1911 nr 72.

67 ”Naprzód” 1 XI 1904 nr 304; „Oświata” 27 IV 1902 nr 9. 
nica śmierci Okrzeji, Barona, Kasprzaka, Proletariatczyków czy rocznica pomordowanych robotników podczas walk barykadowych w Łodzi w czerwcu 1905 r. ${ }^{68}$. Powodem organizowania demonstracji w Galicji przez PPSD, również poza Wszystkimi Swiętymi, były rocznice zgonu znanych socjalistów: Witolda Regera, Kazimierza Mokłowskiego, Antoniego Czerwińskiego, Antoniego Mańkowskiego oraz odsłanianie pomników na cmentarzach. Na Sląsku Cieszyńskim manifestacyjnie obchodzono rocznice katastrof górniczych ${ }^{69}$.

Jeszcze w przeddzień I wojny światowej w Polsce zdarzało się, iż rodziny pozostawiały na grobach zmarłych coś z jadła i przedmiotów, które jak sobie wyobrażano, mogły być pomocą w przyszłym życiu pozagrobowym", aby umarli mogli pokrzepić się raz w roku przynajmniej"70. Były to zwyczaje pamiętające dość odległe czasy. Socjaliści polscy pozostawiając na grobach zmarłych współtowarzyszy czerwone sztandary, transparenty oraz składając nielegalne w zaborze rosyjskim wydawnictwa, książki, broszury i najnowsze wydania gazet $\mathrm{m}$. in. chciały przez to powiedzieć, iż ich praca, wysiłek nie poszły na marne, że dalej stanowią cząstkę wielkiej międzynarodowej społeczności pokrzywdzonych, walczących o nowy, sprawiedliwy ład na ziemi.

Partie socjalistyczne, PPS, później PPS-Frakcja, PPSD składały kwiaty, zapalały znicze i świece a nawet urządzały demonstracje przy grobach polskich powstańców i rewolucjonistów poprzednich epok. W zaborze rosyjskim najczęściej organizowano je w latach poprzedzających rewolucję 1905/07 i w czasie jej trwania. W Lublinie pierwsza w ogóle publiczna manifestacja odbyła się w 1904 r. przy grobie, zmarłego w roku 1890, ks. Piotra Ściegiennego. Jeszcze kilkakrotnie w latach późniejszych PPS urządzała takie manifestacje przy grobie patrona socjalistów polskich, któremu prasa i druki ulotne nie tylko PPS, ale i innych partii robotniczych poświęcały tak dużo uwagi ${ }^{71}$. Żaden z polskich rewolucjonistów 1 połowy XIX stulecia nie był tak dobrze popularyzowany jak ks. Ściegienny. Za sprawą socjalistów odnalazł się w historii i w świadomości historycznej Polaków.

W latach rewolucji PPS zorganizowała jeszcze co najmniej kilkanaście takich cmentarnych demonstracji w różnych miejscowościach, w tym kilka na wiejskich cmentarzach. Najwięcej na Podlasiu i na Lubelszczyźnie. „W Łukowskim 2 listopada przy mogile powstańca - czytamy — licznie zebrani włościanie uczcili pamięć poległych z czerwonym sztandarem i śpiewem naszej pieśni socjalistycznej, tak samo koło Siedlec na mogile poległego powstańca złożono cierniowy wieniec z czerwonymi wstęgami, na którym były napisy: „Od młodzieży PPS” i „Od towarzyszy włościan”72. Demonstracje odbywały się też

\footnotetext{
68 WAP Łódź: PGZŻ 120/1905, 641 k. 7; CAKC mikrofilm 1167/1 (2 IV 1905, Łódź).

${ }^{69}$ Przykładowo w Karwinie, poczynając od 23 czerwca $1895 \mathrm{r}$.

70 "Głos” 3 XI $1901 \mathrm{nr} 42$.

71 "Pobudka” 1 VIII 1905; „Naprzód” 8 XI 1904 nr 310.

72 "Robotnik” 20 I 1905 nr 58; ,Robotnik” 2 XI 1904 nr 54.
} 
i na Litwie. Najbardziej głośne urządzały wspólnie PPS i Litewska SD w Wilnie na miejscu kaźni w roku 1839 Szymona Konarskiego.

W Galicji PPSD urządzała manifestacje przy grobach zmarłych powstańców 1831, lat 1846 - 1849, 1863. We Lwowie, szczególnie uroczyście obchodzono rocznicę stracenia Józefa Kapuścińskiego i Teofila Wiśniowskiego 31 lipca 1846 r. Co roku tego dnia oraz 2 listopada na Górze Straceń zbierały się tłumy mieszkańców Lwowa, nie tylko reprezentujących PPSD ${ }^{73}$. W Krakowie, młodzi robotnicy, od początku lat dziewięćdziesiątych składali wieńce i palili świeczki na grobach powstańców na cmentarzu Rakowickim, we Wszystkich Swiętych zbierali się przy pomniku powstańców roku 1863 . Robotnicy ci występowali wspólnie z rzemieślnikami z kół radykalnych oraz z młodzieżą akademicką, dlatego mniej podkreślali klasowy a bardziej narodowy charakter tych uroczystości, co uzewnętrzniało się m. in. w repertuarze pieśni ${ }^{74}$. Krakowski „Czas” zachęcał policję, by zdecydowanie rozprawiała się z demonstrantami, ale bezpośrednio do interwencji nie dochodziło. W zaborze pruskim, gdzie ślady powstań były mniej widoczne, podobne akcje kierowane przez PPS zaboru pruskiego zdarzały się rzadziej. Przede wszystkim pamiętano o uczestnikach powstania wielkopolskiego 1848 r. (Sokołów), a na grobach powstańców 1863 i 1831 tam zmarłych, jak zwykle, były kwiaty i świece.

Wśród organizatorów takich manifestacji zwraca uwagę brak SDKPiL, co wydaje się zrozumiałe, oddawanie hołdu bowiem szlacheckim rewolucjonistom i uczestnikom powstań byłoby sprzeczne zarówno z jej programem, jak i $\mathrm{z}$ oceną przeszłości. SDKPiL nie chciała mieć nic wspólnego ani z aktualnymi prądami niepodległościowymi, ani z przeszłymi ruchami powstańczymi. Z tych samych powodów sprzeciwiała się śpiewom pieśni religijnych i patriotycznych przez swoich zwolenników, zwłaszcza hymnu „Boże coś Polskę” oraz organizowanym przez PPS po wyjściu z kościołów manifestacji politycznych, gdyż jej się kojarzyły z latami $1860-1863$.

Już na początku lat dziewięćdziesiątych socjaliści polscy „zgłosili” swoje prawa do organizowania tego obszaru świąt religijnych, które bezpośrednio nie wypełniał Kościół. Najwcześniej uczynili to socjaldemokraci z Galicji, którzy w dniach świątecznych, wolnych od pracy dostrzegli dogodny czas do upowszechniania wśród proletariatu, rzemieślników, również mieszkańców wsi swoich celów programowych. „Własne” święta propagowali i organizowali oni zazwyczaj w sposób ostrożny, by nie urazić uczuć religijnych tych środowisk robotniczych i chłopskich, które stopniowo chcieli pozyskać dla idei socjalistycznej. W tej sytuacji świadome działania na rzecz pomniejszenia znaczenia nabożeństw świątecznych i innych praktyk religijnych nie mogły wchodzić w rachubę. Podobnie ze względu na potencjalnych zwolenników i wierzących człon-

${ }^{73}$ W. Opałek, jw., s. 175.

74 WAP Kraków: StGrKr 803 (1890, 1890 - 1893). 
ków partii, polscy socjaliści niezależnie od organizacji, do której przynależeli, nie zamierzali - wzorem francuskich czy belgijskich - tworzyć zupełnie nowych świąt laickich. W drukach polskich partii socjalistycznych, podobnie jak i podczas spotkań $z$ robotnikami trudno by też szukać jakichkolwiek uwag na temat świąt rewolucyjnych, praktykowanych w czasach Wielkiej Rewolucji Francuskiej czy Komuny Paryskiej.

Niemniej, niezależnie od intencji socjalistów, nowe święta oraz inne podobne przedsięwzięcia prowadziły do desakralizacji i do wzrostu obojętności religijnej. Dlatego zostały one krytycznie przyjęte i surowo ocenione przez duchowieństwo. Kościół wielokrotnie dawał wyraz przekonaniu, iż świąteczne imprezy socjalistów wyrywają robotników ze zwykłego kręgu spraw, rodzin, sąsiedztwa i w dłuższej perspektywie czasowej mogą prowadzić do rozejścia się ich w ogóle z religią. Swięta stały się więc jeszcze jedną płaszczyzną konfliktu.

Całotygodniowa praca robotników siłą rzeczy rodziła potrzebę większego urozmaicenia przy spędzaniu wolnego czasu, czego nie mógł bądź nie potrafił wszỳstkim, w wystarczającym stopniu, zagwarantować Kościół. Naprzeciw tym potrzebom wychodziły partie socjalistyczne, które w jakimś skromnym zakresie zaspakajały ich pragnienie zabawy, rozrywki, odpoczynku. Swięta i niedziele dla pewnej, wówczas jeszcze niewielkiej części robotników stawały się czasem spędzanym inaczej niż dotychczas, a rodzina przestawała być dla nich miejscem centralnym.

Nowe wzory świątecznego odpoczynku i rozrywki zaczęły być przyjmowane nie tylko albo nawet nie tyle pod wpływem działalności i propagandy polskich socjalistów, ale na skutek oddziaływania w tym kierunku na społeczeństwo nowej cywilizacji przemysłowej i wielkomiejskiej. W ostatnich zwłaszcza latach poprzedzających wybuch I wojny światowej te wzory coraz szybciej zaczynały przenikać również do inteligencji, rzemieślników a nawet do środowisk wiejskich, przede wszystkim z Galicji. Ale ów proces dopiero się rozpoczynał. Jego dalszy ciąg będzie można śledzić w latach 1918 - 1939.

Skalę zamierzeń i dokonań socjalistów w zakresie organizowania nowych świąt ograniczał m. in. fakt, iż żadna z polskich partii, do lat I wojny światowej, nie wypracowała ich całościowej wizji. Partie nie przyjęły też wiążących zasad ich organizowania, nie ustaliły reguł postępowania jak choćby w przypadku konfliktu z duchowieństwem. Wiele kwestii politycznych, takich jak problem rewolucji, demokratyzacja stosunków politycznych w państwie, formy i metody walki, sprawa chłopska czy narodowa było ujmowanych w teoretycznych modelach, natomiast to jak socjaliści powinni ustosunkować się do praktyk świątecznych i w ogóle praktyk religijnych, jak i do nowej, laickiej obrzędowości, $w$ istocie rozstrzygal dzień bieżący. To nie teoria będzie wytyczać drogę konkretnym działaniom, lecz działalność praktyczna, poprzez kumulowanie doświadczeń zacznie otwierać drogę refleksji, uogólnieniom i teoretycznym wizjom. Ale to nastąpi dopiero w okresie międzywojennym, w latach dwu- 
dziestych, kiedy to przede wszystkim z inicjatywy PPS w mniejszym stopniu polskich komunistów rozpoczną się prace i studia badawcze mające na celu $\mathrm{m}$. in. wypracowanie konceptu tworzenia nowej kultury proletariackiej. Nawiązywały one zresztą do tego, co w tej mierze, w poprzedniej epoce dokonali polscy socjaliści.

\title{
LES PARTIES SOCIALISTES DE LA POLOGNE AU SUJET DES FÊTES RÉLIGIEUSES À LA LIMITE DE XIXe ET XX ${ }^{\mathrm{e}}$ SIĖCLE
}

\author{
Résumé
}

Les socialistes polonais qui agissaient dans les trois parties politiques de la Pologne jusqu'à 1914 prenaient la parole le plus souvent à l'occasion des fêtes (Noel, Pentecôte, veille de la Saint Jean, Toussaint). Ce qui est frappant, dans tous les textes du parti, c'est la ressemblance des jugements portés sur le rôle de classe des fêtes réligieuses.

On estimait ainsi qu'elles sont utiles mais uniquement aux possesseurs et à l'Eglise, en faisant naître l'illusion dangéreuse d'une collaboration harmonieuse entre le monde du travail et celui du capital. Les socialistes polonais, malgré leur opinion négative quant à la fonction des fêtes catholiques, furent loin de réclamer dans leur programme l'annulation de celles-ci, même dans un avenir lointain, bien que ce fût pour d'autres mobiles que ceux des croyants qu'ils se prononcaient pour leur maintien. Par contre ils s'intéressèrent aux modifications des fêtes. Ayant pour objectif une réinterprétation progressive du sens des fêtes catholiques ils ne mettaient pas en doute la nécessité de garder le cérémonial des fêtes réligieuses. Ils estimaient que ce domaine relevait de la sphère purement privée des croyants.

Selon eux, les fêtes n'auraient pas dû constituer seulement une période de repos et de loisirs, mais aussi de travail, bien que moins important que les dimanches, au profit de la société ouvrière et du parti. Ils attribuaient un grand rôle aux réunions de parti pendant les fêtes, ce qui fut, à leur avis, une exellente occasion pour propager les idées socialistes et intégrer les milieux ouvriers. Par contre ces réunions n'avaient pas l'ambition de créer un nouveau cérémonial altérnatif, laîc.

Lors des grandes fêtes annuelles on n'organisait pas, dans la plupart des cas, de manifestations publiques ni de ressemblements. Les socialistes polonais ne voulurent ni ne purent se permettre de propager ouvertement le cérémonial laic. Ils ne le voulurent pas, car ceci ne rentrait pas dans le cadre des principaux objectifs du programme. Ce problème ne les intéressait que dans la mesure où il pourrait faire progresser plus rapidement leur propre conception du système politique. Ils ne le purent pas non plus, même si ceci avait servi leur intéret directement, car cela aurait provoqué un conflit inévitable avec les ouvriers, les artisans et les paysans qu'ils voulaient gagner à leur cause. Néanmoins, indépendamment des intentions des socialistes, les nouvells fêtes menaient à la désacralisation et à l'extension de l'indifférence réligieuse. C'est pour cette raison-là qu'elles furent jugées sévèrement par le clergé. 